\title{
Interpersonal Function of Joe Biden's Victory Speech (Systemic Functional Linguistics View)
}

\section{Hieronimus Canggung Darong1*}

${ }^{1}$ Indonesian Catholic University Santu Paulus Ruteng, Indonesia

\begin{tabular}{l} 
A R T I C L E I N F 0 \\
\hline Article history: \\
Received 10 Desember \\
2020 \\
Received in revised \\
Form 21 January 2020 \\
Accepted 01 February \\
2021 \\
Available online 04 \\
February 2021
\end{tabular}

Keywords:

Interpersonal function,

speech, and SFL

\begin{abstract}
A B S T R A C T
Text analysis was mainly concerned with the ideational function and textual function. Besides, macro aspect has been regarded as the most text structure examined in previous studies. Regardless of those three aspects, this study focused on the interpersonal function analysis of political speech text, by taking an example of Joe Biden's victory speech. The purposed theory namely Systemic Functional Linguistics theory (SFL) was then applied to analyze the text. The analysis was conducted by modifying the speech text into clauses which were subsequently analyzed in accordance with the goal of the analysis. Data analysis revealed that the speech established an intimate relationship and a close distance with the audience. As such, the speaker enables to gain support and exchange information through the use of linguistics resources namely declarative clause in the mood structure, modality, and pronoun "we". As a conclusion, different use of mood, modality, and personal pronouns might determine the different level of interpersonal function of a text. This study has a great impact on language teaching and learning in terms of maintaining social
\end{abstract} relationships and exchanging meanings between teachers and students by taking into account the link between linguistic resources and the nature of texts.

\section{Introduction}

Discourse studies analyze units of language. The coverage deals with not only written text but also in spoken text such as speech, interview, conversation, flyers and so forth. In this respect, we as listeners and readers try to understand every single meaning of the words by carefully examining words, context, and ideology lie behind the text and linking them to each other (Gusthini, Sobarna, \& Amalia, 2018; Kai, 2008; Poulimenou, Stamou, Papavlasopoulos, \& Poulos, 2016; Qian \& Pan, 2019). In other words, discourse covers the use of language in its writers and speakers form. As such, discourse study, thereby, is an attempt to study the organization of language above the sentence or above the clause, and therefore to study larger units, such as conversation exchanges or written text (Stubbs, 1983). Thus, discourse is a generic term as the scope is large.

As a text, speech follows a certain structure, order, viewpoint, and expresses particular values and messages as well. Pushing further, the speech can be regarded as an important social means of communication due to its significant impact on the presentation of cultural, political, and social life (Bao, Zhang, Qu, \& Feng, 2018; Määttä, Puumala, \& Ylikomi, 2021). This to say that speech should be examined from what and how it is expressed, the ideas or information implied, and the speaker's role. As such, it should be constructed in such a way that such examination might be beneficial to reveal the ideology and social context that tightly associated within it. It, therefore, seems important for the text readers or speech listener to possess some knowledge of how the text they read or listen is produced.

In the field, there has been a great number of research studies concerning with speech text. For example an analysis of ideational function which is realized by register category of field of the text (Ademilokun, 2019; Bartley, 2018; Figini, Roccia, \& Rezzano, 2019; Kusuma, Dewi, \& Kurniawan, 2018). The studies found that the field of the speech texts mostly show the action employed by both speaker and audience. Other studies emphasized the textual function of the text (Ahmed \& Al, 2020; Briones, 2016; Leong, 2019; Ong, 2019; Othman, 2020; Potter, 2016; Suparto, 2018). They highlighted that as one of the meta-functions of language, the textual function of the text which is realized by register category of mode was of benefit to deliver the message of the text. The construction of theme and rhyme should be in such a way that help readers or listeners to understand what lies behind the text. 
Differently, other studies emphasized the linguistics, cognitive and psychological aspect of the speaker (Navarro, Macnamara, Glucksberg, \& Andrew, 2020; J. Wang, 2010; W. Wang, 2020). Those aspects in question might determine the message being carried by the speaker or writer in the text. In a more specific aspect, other studies examined the coherence of the text highlighting the word choices, citation techniques, speech acts and semiotic layers (Bu, Connor-linton, \& Wang, 2020; Chu \& Huang, 2020; Risberg \& Lymer, 2020; Hopke \& Simis, 2016; Horváth, 2017). These studies found the words choice and semiotic layers determine the cohesiveness and proposition of a speech delivery. To add on, others concerned with figurative frames, cohesiveness, and structural pattern of a speech texts. Metaphor is regarded as a prevailing way and a rhetoric dimension to frame political issues of political actors in their speech (Kelly, 2020; Moragas-fernández, Calvo, \& Capdevila, 2018; Nartey, 2018). Meanwhile, cohesion devices and other linguistics resources could differently contribute to frame a comprehensive understanding of the characteristics of any kind of genre or text types (da Cunha, 2019; Xuan, 2017; Jitpranne, 2018; Martin Zappavigna, 2029; Schubert, 2019; Silke, Quinn, \& Rieder, 2019; Zhan \& Huang, 2018).

Unlikely, others purposed topic modeling approach, dichotomous framework and socio-pragmatic methodology to discover thematic information within the text (Ahmed, 2017; Boch, 2020; Brookes \& Mcenery, 2019; Fetzer \& Bull, 2012; Schumacher, Hansen, Velden, \& Kunst, 2019). In this regard, Cartagena and Prego-vázquez (2018) and Afzaal (2020) highlighted the importance of socio- discourse competence for both speaker and listener or for both writer and reader However, regardless of the purposed approach, another theory namely Systemic Functional Linguistics was popularly used by researchers and was beneficial theory to reveal to know what and how the text is (Andersen, Emilie, \& Holsting, 2018; Hasan, 2014; Lim, 2018; Montes, Barboza, \& Olascoaga, 2014; Santosa, 2016). In the view of SFL, there are three metafunctions of language namely ideational or experiential function which is realized by the field of a text, interpersonal function contributing the social relationships thereby is realized by the tenor and the textual function dealing with the use of language to construct logical and coherent texts and is realized by the register category of mode. More importantly, under the theory of SFL, context plays important role in constructing a particular text (Baysha, 2019; Heruti, Bergerbest, \& Giora, 2019; Kaneyasu, 2020; Scholman, Demberg, \& Sanders, 2020; Upadhyay, Houghton, \& Klin, 2018). Therefore, aside from linguistic sources, context-dependent in analyzing a speech text might be beneficial for the audience or readers.

Despite the fruitful findings of the previous research studies, what is left is the interpersonal metafunctions of text. The previous studies were particularly mapped into a three-dimensional framework namely micro-structure, meso- structure, and macro structure. This implies that the analysis was about the text's syntax, metaphoric structure, some other surface structure of a language in social, political, and historical dominations. Yet, the text is not only a matter of the structure. It deals also with language function employing the text proposition. As such, the previous studies were, in fact, concerned with the field or the ideational function and the textual function of the text utilizing Systemic Functional Linguistics (SFL). Meanwhile, aside from ideational function (field) and textual function (mode), interpersonal function also exists within a text employing a distinctive character of a particular text (Eggins, 1994; Halliday, 1985). It is an interpretation of language in its function as an exchange and employs speaker's meaning as an intruder considering the interactive nature of relations between the addresser and the addressee. The analysis on it might be beneficial to reveal the relationship and intimacy between the speaker or writer and the reader or listener. As such, it is associated with the term grammar as a resource for expressing and evolving meaning; clause within the text organized as an interactive event between the speaker and audience or between writer and reader.

Again this backdrop, regardless of the constructive structure level of text, ideational function (field) and textual function, this article is an attempt to examine another function of text namely the interpersonal function. The examination utilized SFL theory by taking an example of an American political speech text, Joe Biden's victory speech, based on Systemic Functional Linguistics (SFL) view.

\section{Methods}

As has been mentioned previously, the focus of the analysis of the text under study is to investigate the register of the interpersonal function (tenor). The purposively chosen text was Joe Biden's victory speech who just won the most influential, powerful nation in the world, United States election. As such, I am curious to examine what and how it is through Systemic Functional Linguistics (SFL) theory. Then, it is necessary to note that the text under study, basically, has three major parts namely field, tenor, and mode which according to SFL, constitute the register categories of a text. However, as its scope, the register to analyse in this study is only the interpersonal function that so-called tenor of the text. 
To make the writer easily in doing his analysis, the speech text was modified the text into 199 clauses from which the text is built. The modified texts were, then, analysed in accordance with the goal of the analysis that is interpersonal function which is realized by register category of tenor. In this regard, tenor was seen through the analysis of mood structure as shown in the example of modality, and the use of pronoun which subsequently reveal the interpersonal function of the participants involved in the text.

\section{Result and Discussion}

\section{Result}

It is necessary to note that, there are three ways of reveal the interpersonal function of the text in this study, there namely, mood structure analysis, modality, and the use of the pronoun. After modifying the text into clause (199 clauses), the structure of mood mostly in the system of subject and finite indicating declarative as the most frequent clause used. Table 1 delineates the distribution of clause employing mood structure after the modification process.

Table 1. Distribution of Clause

\begin{tabular}{ccc}
\hline Mood system & Total & \% \\
\hline Declarative & 196 & 98,5 \\
Imperative & 1 & 0,5 \\
Interrogative & 2 & 1 \\
\hline Total & $\mathbf{1 9 9}$ & $\mathbf{1 0 0}$ \\
\hline
\end{tabular}

Concerning the clause appearance, the dominant appearances of 196 declarative clauses in Biden's Victory speech were successful in that they are functioned as statements to give as much as possible information to the audience, through which he succeeded in recalling his presidential election campaign, expressing his gratitude to his supporters, making promises and inspiring the audience to go through the difficulties of the nation.

In terms of modality (Table 2), it was found that 26 modal verbal operators are adopted in the speech. The most frequently adopted one was "will" appearing 18 times. Besides, the text employed other modals appearing respectfully 8 times for modal "can", 3 times for "must" and once for "may."

Table 2. The distribution of Modality

\begin{tabular}{ccccc}
\hline Modal Auxiliary & Will & can & Must & May \\
\hline Modality & Inclination/futurity & ability & obligation & Expectation \\
Frequency & 14 & 8 & 3 & 1 \\
\hline
\end{tabular}

The last aspect to reveal the interpersonal function is that the use of pronouns as shown in Table 3 .

Table 3. The distribution of Pronoun

\begin{tabular}{ccc}
\hline No & Pronoun & Occurrence \\
\hline 1 & I & 31 \\
2 & He & 1 \\
3 & She & 3 \\
4 & You & 13 \\
5 & We & 33 \\
6 & They & 4 \\
\hline
\end{tabular}

The use of the pronoun "we" was dominantly used by Biden during the speech. As such, Biden tends to put the audience as the agent of change in America and go together with him as the president. In this respect, the use of pronoun I might be an emphasis toward the unity between the ruler and citizen. Other pronouns such as you, he, she, and they were used resulting from discourse moves and commodity exchange during the speech with the audience 


\section{Discussion}

To keep the communication going, a component for carrying out the interpersonal metafunction of the clause as the exchange in English language is indispensable. This component is called mood and is made up of subject and finite (Halliday, 1985) The subject supplies the rest of what it takes to form a proposition, namely, something by reference to which the proposition can be affirmed or denied". The Finite refers to the first functional element of the verbal group. When it comes to the roles of addressers and audience, the most fundamental purposes in any exchange are giving or demanding information and goods and services. As noted by Halliday, in any communicative language, there are four basic speech roles: giving information, demanding information, giving goods and services, and demanding goods and services. The usual labels for these functions are the statement, question, offer, and command. The function of the statement is closely associated with a particular grammatical structure, that is, the declarative clauses; the question is related to interrogative clauses; and the command is associated with imperative clauses. The ordering of subject and finite (two elements of the mood system of the clause) in the clause plays an indispensable role in signaling speech roles and the proposition of the text including speech.

Data in Table 1 confirms that Biden likes to give information to the audience regarding what and how America should be. Such declarative clauses were made of mood system employing subject and finite order providing some propositions such as promises in his campaign; the actions would be and his gratitude to the supporters. In this respect, giving information through declarative clauses could make sense. As a dilly employing a political mission, it is urgent and apparent for the speaker to give information and demand services. On one side, the speaker expects to provide certain messages to the audience carrying his political attitude and assumption. On another side, the speaker attempts to demand and arouse the audience, as listener, to take action following the locutionary force of the speaker's words as found by (Gusthini et al., 2018; Risberg \& Lymer, 2020). Therefore, complete declarative clauses commonly dominated and were regarded as a distinctive characteristic of a political speech including Biden's

While in a speech, it is more significant for the addresser to build up an equal and mutually reliant relationship with the audience. As stated by Halliday (1985) there are two kinds of messages conveyed by imperative clauses. They are to command others to do something and is to invite the audience to do something together. The latter is always affected by the format of "Let's". In this text, Joe Biden chose "let us" as an imperative clause to indicate that he was not giving a direct command but making a suggestion, conviction, and persuasion. Besides, with the employment of "let us" he successfully shortened the distance between him as the speaker and the audience which subsequently called on them to take actions together in facing the challenges ahead. In this regard, the imperative clauses used in Biden's Victory Speech were more moving, appealing, and inspiring to the audience as shown in the following examples.

But now, let's give each other a chance

It's time to put away the harsh rhetoric

To lower the temperature

To see each other again

To listen to each other again

With an imperative clause in the data, Biden maintained an equal and reliant or dependent relation with the audience which might be helpful in moving the audience with emotion. Thus, he could win extensive supporters and advocates. The mood system in which declarative and imperative clause found in this study corroborated previous studies saying that linguistics resources might differently contribute to frame a comprehensive understanding of the characteristics of any kinds of the genre (Da Cunha, 2019; Mubarak \& Batam, 2007; Schubert, 2019; Silke et al., 2019; Zhan \& Huang, 2018).

In the meantime, even the interrogative clause was not a widespread choice in a speech, but the appropriate usage of the interrogative clause could help to create an intimate dialogic style. The audience considered that they were friends with the addresser and naturally share his same proposal as delineated in the following examples.

What is the people's will?

What is our mandate?

Apparently, through these rhetorical questions, Biden successfully attracted the audience's attention emphasized that the audience thinks and rouse the passion for overcoming the current difficulties. This corroborates previous studies reporting that a prevailing way to frame political issues of political actors is and a rhetoric dimension (Kelly, 2020; Moragas-fernández, Calvo, \& Capdevila, 2018; Nartey, 2018). 
Aside from the imperative and modulated interrogative structures, there is still another way of getting people to do things or not to do things, that is, modality (Table 2). It plays an important role in carrying out the interpersonal metafunction of clauses showing to what degree the proposition is valid. Modality refers to the space between "yes" and "no", showing the speaker's judgments of the probabilities or the obligations involved in what she is saying. One of the most common ways for the realization of modality as a function of the Mood. When realized by modal verbal operators, modality involves degrees and scales about the validity of a proposition coining the term "Modal Commitment". It reflects the previous findings saying that text types is mostly influenced by the use of modality as implicitly regarded as grammar conformity (Bao et al., 2018; Bu et al., 2020). In this regard, Eggins (1994) has mentioned three main values of modal commitment are high, median and low on the scale. As such, such different scales of modal commitment differently lead to meanings. Meanwhile, Eggins (1994) states that modality may comprise modalisation and Modulation. The former is concerned with the speaker's judgment of the validity of the proposition and includes the scale in terms of probability (possible-probable-certain) and usuality (sometimes-usually-always). The latter deals with how confident the speaker can be in the eventual success of the exchange covering the inclination (willing-keen-determined and the degree of obligation (allowed-supposed-required).

It was found that 26 modal verbal operators are adopted by Biden in his Victory Speech, of which, the most frequently adopted ones are as the following: "will" turns up for 14 times, "can" is adopted for 8 times, "must" turns up for 1 time and "may" is used once. Regarding the use of "Will", it is adopted to predict the future or as being a marker of the future as shown in the following clauses. In the meantime, Biden also used "will" as a modal verbal operator to show "strong wish and determination"

That plan will be built on a bedrock of Science

I will be constructed out of compassion, emphatic, and concern

I will spare no effort or commitment to turn this pandemic around

I run as a proud Democrat

I will now be an American President

I will work hard for those who didn't vote me as for those who did

As it is mentioned, different scales of modal commitment lead to different meanings. "will" which represents a higher scale of modal commitment signals a higher degree of certainty about the validity of a proposition. Thus, the constant use of "will" in this speech was successful in terms of showing Biden's strong mind and keen desire to lead American and go through the challenges ahead. Meanwhile, the higher modal commitment of "will" further confirmed that more actions will be definitely taken in the future. Thus, in his speech, Biden likely to give hope and anticipated the future using "will" rather than enforcing on his people, through which, a good relationship was well- established.

Differently, on one side, "can" representing a low-value modulation. Permission of "can" is seen as the lowest degree of pressure, opening the possibility for the other person to do the action but leaving the decision to them.

\section{We have the opportunity to defeat despair}

And build the nations of prosperity and purpose

We can do it. I know we can

Biden used "can" to weaken his authority, to shorten the distance between him and the audience and not to force and command them to follow his instruction. On the other side, the semantic meaning of "can" indicates the ability to do something. The constant employment of "can" here was to encourage American to believe in themselves; to be confident that they have the ability to do anything; telling the nation that even though the country was probably in its darkest days, there will be a hope; there will be a chance to turn it around and climb back into the light.

"Must" representing the highest scale of modal commitment; signals the highest degree of pressure on the other person to carry out a command. "Must" is sometimes adopted in a political speech in that the addresser needs to show his firm determination, to call on the audience to be determined to take action in achieving their common objectives. In this speech, the use of "must" as in the three examples "to make progress, we must stop treating our opponents as our enemy", "we must make the promise of the country real for everybody", we must restore the soul of America "were beneficial to show Biden's firm determination to overcome the challenges and call on the American to take strong actions to achieve their targets. While "May" as was used in the last clause "and may God protect our troops" shows the expectation Biden to the stately of the troops. Thus, modality can be in the form of obligation, inclination, expectation, and necessity. As such, the modality of the text under study indicates strong ability, promises, and plans. 
This judgment is supported by the fact that Biden mostly used "can" to indicate his strong ability in arousing the audience and "will" (inclination/futurity) more often than other modals.

In contrast with Horváth (2017) and Hopke and Simis (2016) saying that the combination of actions and verbal resources were beneficial to co-narrate stories or texts, in this study, the findings supports the previous study saying that the power of words in employing word choices is more than action (Bartley, 2018; Gusthini et al., 2018; Määttä et al., 2021; Poulimenou et al., 2016; Tolochko \& Boomgaarden, 2017). It conveys a belief and encouragement that the speaker himself and Americans have to believe in themselves in doing anything for America. In other words, the use of "can", "must" and "will "indicates strong expectations and toughness of the speakers to do the actions involving plans, promises for the American future. Thus, the ways of presenting information in a text is a verb-dependent constituting a process type with each verb contributing to the intended meaning of the structure

Regarding the use of pronoun (Table 3), Biden used "I" to speak of his election campaign and expressed his gratitude as shown in the following clauses

I am humbled by the trust and confidence you have place in me

I pledge to be a president

From the clauses above, the use of the pronoun "I" successfully described the newly elected president into a sincere person who will remember the gratitude and try to repay it. Besides, the use of I indicated the strong of I (Biden himself) as the main agent of America. The pronoun I represents the main doer of every action taken for America.

I will spare no effort or commitment

To turn this pandemic around.

I ran as a proud democrat.

I will now be an American president.

I will work as hard for those who didn't vote me and who did

Meanwhile the second personal pronoun "you" had a significant role in this speech due to its function in creating a dialogic style during the speech and maintaining a close intimate relation between the addresser and the audience. Thus, it ensured the effective interaction of the addresser and the audience during the speech as shown in the following examples:

Kamala, Doug like it or not, you are family

You have become honorary Biden's and there's no way out

To all those who volunteered, work the polls in the middle of this pandemic, local election officials, you deserve a special thanks from this nation.

To my campaign team, and all volunteers, to all those gave so much of themselves to make this moment possible, I owe you everything

Here, "you" was not only used to attract the audience's attention but also made them feel that they were making a dialogue with their friend (the addresses). With "you" Biden performed his care and respect to the audience, thus a close intimate relation was maintained and shared the same attitude and assumption of the addressers.

More interestingly, the personal pronoun "we" appeared at a high rate as personal pronouns in Biden's victory speech. The use of pronoun "we" show that Biden and all the Americans were in the same boat as shown in the following examples:

We stand again at an inflection point.

We have the opportunity to defeat despair and to build a nation of prosperity and purpose.

We can do it.

I know we can

I've long talked about the battle for the soul of America

We must restore the soul of America

In this respect, Biden successfully shortened the distance between him and the audience and maintained an equal and reliant relationship. It greatly helped him to persuade the audience to share the same proposal that is to take actions to go through the difficulties of the country. Pronoun "we", which holds an exclusive meaning, was a signal that Biden and his government and with all American were a strong team with high spirits, holding powerful authority and determination to lead their nation to a bright future. So, the exclusive use of the pronoun "we" helped Biden to win Americans' great confidence in the newly elected government. 
Overall, this political speech successfully created a dialogic style, which successfully shortened the distance between the speaker and Americans. The employment of "I", "you" and "We" was significant for Biden to win widespread support for his new government. The pronoun "We" which was mostly used was regarded as a sense of togetherness. It refered to the power of being hand in hand to go to the bright future of America. The speaker (Biden) involved the audience or Americans in his speech. Without them he is nothing. As such, it mirrors previous study highlighting a strategy management of keeping distance between the speaker and the audience (Bu et al., 2020; Fernández-agüero \& Chancay-cedeño, 2019; Qian \& Pan, 2019). Saying it differently, the use of "we" in this speech tends to show that the speaker did not separate himself from the audience and did not put himself as the only agent of change. He, on the other hand, focused and involved the audience to go through for America and not I as the speaker, as the agent of the change. In this respect, the more speaker uses "we", the closer relationship he had with the audience. Meanwhile, other pronouns such as "he" and "they" which refer to particular participants of the speech text, did not significantly carry to the interpersonal relationship between the speaker and the audience or Americans.

By and large, the use of mood system, modality, and pronoun in the speech text under study indicate the high power or solidarity, good intimacy, and familiarity as well. In this regard, this findings mirrors the previous findings saying that cohesion devices and other linguistics resources might differently contribute to frame a comprehensive understanding of the characteristics of any kind of text (Schubert, 2019; Silke et al., 2019; Yin, 2017; Zhan \& Huang, 2018) and the socio discourse competence is of benefit in constructing certain text (Afzaal, 2020; Cartagena \& Prego-vázquez, 2018; Määttä et al., 2021; Navarro et al., 2020).

Of greater importance of this finding is that there should be functional description of context implying meaning, system, and metafunctions of language as purposed by SFL. In terms of interpersonal function, SFL was proven useful perspective to reveal what and how speech text is. This reflects Andersen et al., (2018); Hasan (2014); Lim (2018); Montes et al., (2014); Santosa (2016) studies saying that SFL is and might be of benefit to analyze a text. By employing SFL theory, we can know that a particular text may employ a particular distinctive characteristic interpersonal function by means of context and linguistics source used. Thus, the text should be revealed in such a way that it might not only cope with the structure level but also the discourse-semantics aspects employing not only experiential and textual functions but also interpersonal function which all can be revealed by the use of SFL perspective as in this present study.

\section{Conclusion}

Different use of mood, modality, and personal pronouns might determine the different level of interpersonal function, thus endowing the speaker different status and different purposes, and the influence on the audience. The text under study employs the interpersonal function utilizing declarative mood through which the speaker took the role of information processor and deliverer. Furthermore, the speaker established an intimate relationship with the audience (American), which enables him to gain support and exchange the information with them. This study has a pedagogical implication. In the context of teaching, what is essential to be successful in language learning is interaction. Students' failures in communication which result in the negotiation of meaning, requests for explanation, or reorganization of message contribute to classroom interaction interpersonally. Understanding how the interpersonal function of language might make it possible for teachers and students to interact, to exchange meanings, and to take a stand effectively. Of greater importance is that such understanding leads the classroom agents to maintain the relationship with each other, influences behavior, and knows how to expresses their viewpoints. As such, it is realized by certain grammatical features such as the order of subject and finite, modality, pronoun showing how information is exchanged. In other words, one challenging aspect of language learning is about how to evolve and maintain social relationships in interactions. These challenges might be well-managed by looking at fruitful linguistic resources used namely, the mood system, modality, and the use of pronoun following the discourse move occurring during classroom interactions using SFL perspective.

\section{References}

Ademilokun, M. . (2019). Corpus-Assisted Critical Discourse Analysis of Modality in Social Transformation Campaigns in Nigeria. Discourse and Interaction, 12(2), 5-28. https://doi.org/https://doi.org/10.5817/DI2019-2-5. 
Afzaal, M. (2020). Book reviews. Discourse Studies, 22(5), 632-643. https://doi.org/10.1177/1461445620921656.

Ahmed, M., \& Al, A. (2020). Discourse markers of Moo in Iraqi colloquial language. Discourse Studies, 22(5), 1-14. https://doi.org/10.1177/1461445620916362.

Andersen, T. H., Emilie, A., \& Holsting, M. (2018). Clause Complexing in Systemic Functional Lingustics towards an Alternative Description. Functional Lingusitics, 5(10), 1-25. https://doi.org/https://doi.org/10.1186/s40554-018-0059-7.

Bao, C., Zhang, X., Qu, Y., \& Feng, Z. (2018). American English Perfect Construction Across Registers. $\begin{array}{llll}\text { Journal of } \quad \text { Quantitative } & \text { Linguistics, }\end{array}$ https://doi.org/10.1080/09296174.2017.1387961.

Bartley, L. V. (2018). Putting Transitivity to the Test: A Review of the Sydney and Cardiff models. Functional Lingusitics, 5(4), 1-21. https://doi.org/10.1186/s40554-018-0056-X.

Baysha, O. (2019). Dehumanizing Political Others: A Discursive- material Perspective. Critical Discourse Studies, 17(3), 1-16. https://doi.org/10.1080/17405904.2019.1567364.

Boch, A. (2020). Increasing American Political Tolerance: A Framework Excluding Hate Speech. Socius: Sociological Research for a Dynamic World Volume, 6, 1-12. https://doi.org/10.1177/2378023120903959.

Briones, R. R. Y. (2016). Textual Analysis through Systemic Functional Linguistics. Journal of English Language Teaching and Linguistics (JELTL) Journal of English Language Teaching and Linguistics, 1(2), 109-144. https://dx.doi.org/10.21462/jeltl.v1i2.27.

Brookes, G., \& Mcenery, T. (2019). The utility of topic modelling for discourse studies: A critical evaluation. Discourse Studies, 21(1), 3-21. https://doi.org/10.1177/1461445618814032.

$\mathrm{Bu}, \mathrm{H}$., Connor-linton, J., \& Wang, L. (2020). Linguistic Variation in the Discourse of Corporate Annual Reports: A multi-dimensional Analysis. Discourse Studies, 22(6), 1-31. https://doi.org/10.1177/1461445620928231.

Cartagena, M. C. C., \& Prego-vázquez, G. (2018). Participation frameworks and socio-discursive competence in young children : The role of multimodal strategies. Discourse Studies, 21(2), 1-24. https://doi.org/10.1177/1461445618802656.

Chu, R., \& Huang, C.-T. (2020). The day after the Apology: A Critical Discourse Analysis of President Tsai ' s National Apology to Taiwan' s Indigenous Peoples. Discourse Studies, 23(1), 1-18. https://doi.org/10.1177/1461445620942875.

Da Cunha, I. (2019). A corpus-based analysis of textual genres in the administration domain. Disocurse Studies, 22(1), 1-29. https://doi.org/10.1177/1461445619887538.

Eggins, S. (1994). An Introduction to Systemic Functional Linguistics. Pinter.

Fernández-agüero, M., \& Chancay-cedeño, C. (2019). Interculturality in the Language Class - Teachers ' Intercultural Practices in Ecuador. RELC Journal, 50(1), 164-178. https://doi.org/10.1177/0033688218755847.

Fetzer, A., \& Bull, P. (2012). Doing leadership in political speech : Semantic processes and pragmatic inferences. Discourse \& Society, 23(2), 127-144. https://doi.org/10.1177/0957926511431510.

Figini, F., Roccia, V., \& Rezzano, N. S. (2019). The Construction of Field in Science Popularization Stories. International Journal of Systemic Functional Linguistics, 2(1), 1-13. https://www.ejournal.warmadewa.ac.id/index.php/ijsfl/article/view/669.

Fortanet, I. (2005). Honoris Causa speeches: an approach to structure. Discourse Studies, 7(1), 31-51. https://doi.org/10.1177\%2F1461445605048766.

Gusthini, M., Sobarna, C., \& Amalia, R. M. (2018). A Pragmatic Study of Speech as an Instrument of Power: Analysis of the 2016 USA Presidential Debate. Studies in English Language and Education, 5(1), 97-113. https://doi.org/https://doi.org/10.24815/siele.v5i1.6906.

Halliday, M. A. K. (1985). Introduction to Functional Grammar. Edward Arnold.

Hasan, R. (2014). Towards a Paradigmatic Description of Context: Systems, Metafunctions, and Semantics. Functional Lingusitics, 1(9), 1-54. https://doi.org/http://www.functionallinguistics.com/content/.

Heruti, V., Bergerbest, D., \& Giora, R. (2019). A Linguistic or Pictorial Context: Does It Make a Difference? Discourse Processes, 56(8), 1-16. https://doi.org/10.1080/0163853X.2019.1565277. 
Hopke, J. E., \& Simis, M. (2016). Response to 'Word choice as political speech ': Hydraulic fracturing is a partisan issue. Public Understanding of Science, 26(1), 124-126. https://doi.org/10.1177/0963662516643621.

Horváth, J. (2017). Critical discourse analysis of Obama's political discourse. In Language, Literature and Culture in a Changing Transatlantic World International Conference Proceedings, University Library of Prešov University (pp. 45-56).

Kai, J. (2008). Lexical Cohesion Pattersn in NS and NNS Dissertation Abstracts in Applied Linguistics: A Comparative Study. The Linguistics Journal, 3(3), 132-144. https://www.researchgate.net/profile/Ning_Zhang126/publication/253961492_Existential_Coda _Constructions_as_Internally_Headed_Relative_Clause_Constructions/links/0046353c06ff52b14c 000000/Existential-Coda-Constructions-as-Internally-Headed-Relative-ClauseConstructions.pdf\#page $=132$.

Kaneyasu, M. (2020). Expectations for ' Natural ' Ways of Talking: A context- dependent Perspective on Fixedness in Conversation. Discourse Studies, 23(1), 1-18. https://doi.org/10.1177/1461445620947934.

Kelly, C. R. (2020). Donald J . Trump and the rhetoric of ressentiment. Quarterly Journal of Speech, 106(1), 2-24. https://doi.org/10.1080/00335630.2019.1698756.

Kusuma, R., Dewi, S., \& Kurniawan, E. (2018). Seeing Recount from Systemic Functional Linguistic Perspective: Sine Qua Non Attributes. RETORIKA: Jurnal Ilmu Bahasa, 4(1), 43-52. https://doi.org/ 10.22225/jr.4.1.464.43-52.

Leong, P. A. (2019). Visualizing Texts: A tool for Generating Thematic-Progression Diagrams. Functional Lingusitics, 6(4), 1-13. https://doi.org/10.1186/s40554-019-0069-0.

Lim, F. V. (2018). Developing a systemic Functional Approach to Teach Multimodal Literacy. Functional Lingusitics, 5(13), 1-17. https://doi.org/10.1186/s40554-018-0066-8.

Määttä, S. K., Puumala, E., \& Ylikomi, R. (2021). Linguistic, Psychological and Epistemic Vulnerability in Asylum Procedures: An Interdisciplinary Approach. Discourse Studies, 23(1), 46-66. https://doi.org/10.1177/1461445620942909.

Mendoza-denton, N., \& Jannedy, S. (2011). Semiotic Layering through Gesture and Intonation: A Case Study of Complementary and Supplementary Multimodality in Political Speech. Journal of English Linguistics, 39(3), 265-299. https://doi.org/10.1177/0075424211405941.

Montes, P. A. ., Barboza, A. M. ., \& Olascoaga, A. I. . (2014). Systemic Functional Linguistics and Discourse Analysis as Alternatives When Dealing With Texts. Profile, 16(2), 101-116. http://dx.doi.org/10.15446/profile.v16n2.38113.

Moragas-fernández, C. M., Calvo, M. M., \& Capdevila, A. (2018). The process en route: the metaphor of the journey as the dominant narrative for the political discourse in Catalonia. Critical Discourse Studies, 15(5), 1-23. https://doi.org/10.1080/17405904.2018.1468787.

Mubarak, Z. H. (2014). An Analysis of Cohesion Devices in Political News of the Jakarta Post: A Discourse Analysis Approach. Jurnal Basis UPB, 1(2), 1-12.

Nartey, M. (2018). ' I shall prosecute a ruthless war on these monsters ...': a critical metaphor analysis of discourse of resistance in the rhetoric of Kwame Nkrumah. Critical Discourse Studies, 16(2), 1-18. https://doi.org/10.1080/17405904.2018.1535987.

Navarro, E., Macnamara, B. N., Glucksberg, S., \& Andrew, R. A. (2020). What Influences Successful Communication? An Examination of Cognitive Load and Individual Differences. Discourse Processes, 57(10), 1-20. https://doi.org/10.1080/0163853X.2020.1829936.

Ong, J. (2019). A Case Study of Classroom Discourse Analysis of Teacher's Fronted Reading Comprehension Lessons for Vocabulary Learning Opportunities. RELC Journal, 50(1), 1118-1135. https://doi.org/10.1177/0033688217730138.

Othman, W. (2020). Causal Relations on a Cline of Explicitness: An SFL Perspective. Functional Lingusitics, 7(2), 1-14. https://doi.org/ 10.1186/s40554-020-00071-2.

Potter, L. (2016). Ideological Representations and Theme-Rheme Analysis in English and Arabic news Reports: A systemic Functional Approach. Functional Linguistics, 3(5), 1-20. https://doi.org/10.1186/s40554-016-0028-y. 
Poulimenou, S., Stamou, S., Papavlasopoulos, S., \& Poulos, M. (2016). Short Text Coherence Hypothesis. $\begin{array}{llll}\text { Journal of } & \text { Quantitative 23(2), Linguistics, }\end{array}$ https://doi.org/10.1080/09296174.2016.1142328.

Qian, D. D., \& Pan, M. (2019). Politeness in Business Communication: Investigating English Modal Sequences in Chinese Learners' Letter Writing. RELC Journal, 50(1), 20-36. https://doi.org/10.1177/0033688217730142.

Risberg, J., \& Lymer, G. (2020). Requests and Know-how Questions : Initiating instruction in Workplace Interaction. Discourse Studies, 22(6), 753-776. https://doi.org/10.1177/1461445620928239.

Santosa, R. (2016). Critical Discourse Analysis (CDA): Systemic Functional Linguistics (SFL). International Seminar Prasasti III: Current Research in Linguistics, 46-57. https://doi.org/10.20961/pras.v0i0.1442.g1336.

Scholman, M. C. J., Demberg, V., \& Sanders, T. J. M. (2020). Individual Differences in Expecting Coherence Relations: Exploring the Variability in Sensitivity to Contextual Signals in Discourse. Discourse Processes, 57(10), 1-18. https://doi.org/10.1080/0163853X.2020.1813492.

Schubert, C. (2019). ' OK, well , first of all , let me say ...': Discursive uses of response initiators in US presidential primary debates. Discourse Studies, 21(4), 438-457. https://doi.org/10.1177/1461445619842734.

Schumacher, G., Hansen, D., Velden, M. A. C. G. Van Der, \& Kunst, S. (2019). A new dataset of Dutch and Danish party congress speeches. Research and Politics, 6(2), 1-7. https://doi.org/10.1177/2053168019838352.

Silke, H., Quinn, F., \& Rieder, M. (2019). Telling the truth about power? Journalism discourses and the facilitation of inequality. Critical Discourse Studies, 16(3), 1-7. https://doi.org/10.1080/17405904.2019.1568897.

Stubbs, M. (1983). Discourse Analysis: The Sociolinguistic Analysis of Natural Language. University of Chicago.

Suparto, A. D. (2018). Analisis Ketransitifan dalam Framing Artikel Berita Online. Ranah: Jurnal Kajian Bahasa, 7(1), 16-32. https://doi.org/10.26499/rnh.v7i1.586 (C2018.

Tolochko, P., \& Boomgaarden, H. G. (2017). Analysis of Linguistic Complexity in Professional and Citizen Media. Journalism Studies, $19(12), \quad$ 1786-1803. https://doi.org/10.1080/1461670X.2017.1305285.

Upadhyay, S. S. N., Houghton, K. J., \& Klin, C. M. (2018). Is “ Few " Always Less than Expected ?: The Influence of Story Context on Readers ' Interpretation of Natural Language Quantifiers. Discourse Processes, 56(8), 1-20. https://doi.org/10.1080/0163853X.2018.1557006.

Wang, J. (2010). A Critical Discourse Analysis of Barack Obama s Speeches. Journal of Language Teaching and Research, 1(3), 254-261. https://doi.org/10.4304/jltr.1.3.254-261.

Wang, W. (2020). Grammatical Conformity in Question-answer Sequences: The Case of Meiyou in $\begin{array}{lllll}\text { Mandarin } & \text { Conversation. } & \text { Doscourse }\end{array}$ https://doi.org/10.1177/1461445620916371.

Yin, Z. (2017). Principles of Teaching Cohesion in the English Language Classroom. RELC Journal, 49(3), 118. https://doi.org/10.1177/0033688217707628.

Zhan, H., \& Huang, S. (2018). Critical genre analysis: investigating interdiscursive performance in professional practice. Critical Discourse Studies, 15(5), 1-4. https://doi.org/10.1080/17405904.2018.1468788. 